\title{
THE ROLE OF ANTHROPOMETRIC PARAMETERS AND PHYSICAL ACTIVITY LEVEL IN PATIENTS WITH ACUTE CORONARY SYNDROME ADMITTED TO THE INTENSIVE CARDIAC CARE UNIT
}

\author{
Zdravko Babić, ${ }^{1,2,3,4}$, Ivan Zeljković ${ }^{4}$, Hrvoje Pintarićc ${ }^{5,6}$, Mislav Vrsalović ${ }^{3,4}$, \\ Marko Mornar Jelavić6,7 and Marjeta Mišigoj-Duraković ${ }^{2}$ \\ ${ }^{1}$ Coronary Care Unit, Sestre milosrdnice University Hospital Centre, Zagreb, Croatia; \\ ${ }^{2}$ Faculty of Kinesiology, University of Zagreb, Zagreb, Croatia; \\ ${ }^{3}$ School of Medicine, University of Zagreb, Zagreb, Croatia; \\ ${ }^{4}$ Department of Cardiology, Sestre milosrdnice University Hospital Centre, Zagreb, Croatia; \\ ${ }^{5}$ Department of Emergency Medicine, Sestre milosrdnice University Hospital Centre, Zagreb, Croatia; \\ ${ }^{6}$ School of Dental Medicine, University of Zagreb, Zagreb, Croatia; \\ ${ }^{7}$ Institute for Cardiovascular Prevention and Rehabilitation, Zagreb, Croatia
}

\begin{abstract}
SUMMARY - Anthropometric parameters have a role in diagnosing obesity, which increases the risk of acute coronary syndrome (ACS). The aim of the study was to assess the impact of obesity and physical activity level on the severity and long-term prognosis of ACS. A total of 116 patients with ACS were analyzed according to baseline (demography, medical history, anthropometry), severity (clinical presentation, in-hospital complications, laboratory, echocardiography, coronary angiography) and prognostic parameters (major adverse cardiovascular events during a six-year period). The levels of obesity and physical activity (Baecke/Lipid Research Clinics physical activity questionnaires) were compared with a sample of the Croatian general population. Study results showed the subjects with a higher number of narrowed coronary arteries (CAs) to have higher body mass index (BMI) and waist circumference (WC); those with stenosed left anterior descending artery and anterior myocardial infarction (MI) had higher BMI; waist-to-hip ratio (WHR) positively correlated with creatine kinase and negatively with left ventricle ejection fraction $(\mathrm{p}<0.05)$. Inactive patients more often had multivessel coronary disease and anterior MI; patients with a higher leisure physical activity index had a lower number of affected CAs, lower rate of stent implantations and lower stent length, while those with a higher work physical activity index had a lower rate of anterior $\mathrm{MI}(\mathrm{p}<0.05)$. During the follow-up, inactive patients had more strokes and deaths $(\mathrm{p}<0.05)$. Our patients had higher body weight, WC and WHR, as well as lower leisure time and total physical activity indices than the general population $(p<0.05)$. In conclusion, ACS is less severe and has better long-term prognosis in less obese patients with a higher level of physical activity. Patients with ACS are more obese and have lower total, as well as leisure time physical activity indices than the general population.
\end{abstract}

Key words: Physical activity; Anthropometry; Acute coronary syndrome; Baecke questionnaire; Lipid Research Clinics physical activity questionnaire; Prognosis

\section{Introduction}

Sedentary lifestyle and obesity present an increasing problem worldwide. Obesity and physical inactivity are major independent risk factors for the develop-
Correspondence to: Zdravko Babic, $M D, P h D$, Coronary Care Unit, Sestre milosrdnice University Hospital Centre, Vinogradska c. 29, HR-10000 Zagreb, Croatia

E-mail: zbabic@net.hr

Received February 3, 2020, accepted February 27, 2020 
ment of cardiovascular diseases, as well as other chronic diseases and all-cause mortality ${ }^{1-3}$. Also, regular physical activity (PA) is one of the most important factors in the prevention and treatment of the majority of other risk factors of cardiovascular diseases ${ }^{4-6}$. Multiple epidemiological and clinical studies confirmed the overall benefit of PA in the reduction of the risk of coronary artery disease (CAD) development, as well as of the symptoms in patients with already developed $\mathrm{CAD}^{1-6}$

The American College of Sports Medicine recommends optimal level, type, quantity and intensity of PA for achievement of health benefits ${ }^{7}$. Regular PA and exercise training positively influence a number of cardiovascular risk factors at the same time. Prescribing PA and training is life-long and should include fitness, as well as strength and endurance training ${ }^{8}$.

Obesity as a cardiovascular risk factor can be estimated and compared using different well-known anthropometric parameters. Body mass, body mass index (BMI), waist circumference (WC) and waist-to-hip ratio (WHR) are mostly used in the literature without consensus which of them is the most accurate parameter for that purpose ${ }^{2-6}$. Methods of PA estimation in large groups are direct (questionnaires, PA diaries, mechanical or electronic movement sensors) and indirect (anthropometric and body composition evaluation, energy uptake measurement, clinical and laboratory findings, functional capacity tests, different population indicators). An example of a well-constructed questionnaire that carefully analyzes the most frequent types of light PA is the questionnaire designed by Baecke et al. (Baecke questionnaire) 9 . High validity and repeatability of Baecke questionnaire have been demonstrated in studies investigating cardiovascular diseases and associated risk, as well as other diseases in both genders, different age and ethnic groups, and work intensity ${ }^{10-12}$.

The Lipid Research Clinics physical activity (LRC PA) questionnaire is a simple, global assessment tool devised for differentiating trained versus untrained individuals for the purpose of selecting target heart rates for treadmill graded exercise testing in the LRC Programs Prevalence Study and Coronary Primary Prevention Trial ${ }^{13}$.

The main objectives of this study were to assess the impact of obesity level (body mass, BMI, WC and WHR) and PA level (Baecke and LRC PA question- naires) on the severity and long-term prognosis of acute coronary syndrome (ACS) in patients admitted to the Intensive Cardiac Care Unit; and to compare the obesity and PA level with a representative sample of the Croatian general population.

\section{Patients and Methods}

\section{Study design}

This study was performed at the Department of Cardiology, Sestre milosrdnice University Hospital Centre, Zagreb, Croatia. At first, it included 196 consecutive patients with ACS admitted to the Intensive Cardiac Care Unit during the study period from March 2002 until September 2005. The exclusion criteria were previous myocardial infarction (MI), previous coronary intervention, malignancy, chronic renal failure, and lack of informed consent. Then, $116 \mathrm{pa}-$ tients fulfilled the inclusion/exclusion criteria and participated in the study. The investigation was performed in accordance with ethical standards laid down in the Declaration of Helsinki and approved by the Sestre milosrdnice University Hospital Center Ethics Committee. Patients were classified into three groups according to the European Society of Cardiology (ESC) criteria $^{14,15}$, as follows: group A, unstable angina pectoris (UAP); group $\mathrm{B}$, acute $\mathrm{MI}$ without ST-segment elevation (NSTEMI); and group C, acute MI with ST-elevation (STEMI).

\section{Data collection}

Baseline parameters included age, gender, anthropometry (body height and weight, BMI, WC and WHR), hypertension, diabetes, dyslipidemia, and smoking. Patients filled in Baecke ${ }^{9}$ and LRC PA questionnaires ${ }^{13}$ by themselves or with the help of investigators. Baecke questionnaire consists of 16 items, checking physical workload, load during sports activity and load during leisure time. Three basic indices were calculated from the results of this questionnaire, i.e. work index (WI), sports index (SI) and leisure time index (LI). The lowest possible value of the indices was 1.0, representing the lowest PA, whereas 5.0 was the highest possible value, signifying the highest PA. Total index (TI) was calculated as an average of the three indices?

In the LRC PA questionnaire, the first two questions ask subjects to rate their level of PA relative to 
peers at work and leisure. The third question asks subjects if they regularly engage in strenuous exercise or hard physical labor. If the answer is yes to the third question, subjects are asked if they engage in such activities at least three times a week. In the two-point scoring system investigated, patients who reported strenuous activity were called active, all other were classified as inactive. In the four-point scoring system, among those reporting strenuous exercise (active in the two-point scoring system), those who indicated that they were more active than their peers were classified as highly active, and those who thought they were as active as their peers were classified as moderately active. Among those reporting no strenuous exercise (inactive in the two-point scoring system), those who indicated that they were as active as their peers were classified as low active, and those who thought they were less active than their peers were classified as very low active ${ }^{13}$. Data on obesity and PA level, as well as Baecke questionnaire indices of a representative sample of the Croatian general population (according to age, gender, place of living) were obtained from the study by Heimer et al. ${ }^{16}$.

\section{Severity parameters}

The severity of ACS was estimated by ST-segment changes on electrocardiogram (ECG), clinical presentation (angina pectoris, dyspnea, length of hospital stay), in-hospital complications (arrhythmias, heart failure, cardiogenic shock, cardiac arrest, mechanical ventilation, mitral regurgitation, rupture of interventricular septum or free wall, hospitalization at Coronary Care Unit, mortality), as well as coronary angiography findings (number and length of stenosis in epicardial coronary arteries), necessity for revascularization (percutaneous coronary intervention (PCI) or coronary artery bypass graft $(\mathrm{CABG}))$, laboratory (maximal cardiac troponin $\mathrm{T}(\mathrm{cTnT})$ and creatine kinase (CK) levels) and echocardiography (left ventricular ejection fraction (LVEF)) findings.

A 12-lead ECG was recorded on admission, every 6 hours for the first two days, and once a day during hospital stay. CK levels were measured on admission and every 6 hours until they decreased (Olympus 680, Beckman Coulter Inc., California, USA). Serum cTnT levels were measured twice, i.e. 6 and 24 hours after symptom onset (electrochemiluminescence (ECL) assay (Cobas e411, Roche Diagnostics, Sussex, UK)).
Maximal CK and cTnT values were considered on analysis. During hospital stay, echocardiography (Acuson Sequoia 512, Siemens, Munich, Germany) was performed in all patients according to clinical standards and current echocardiography guidelines. Coronary angiography and PCI of the culprit lesion were performed according to the European Society of Cardiology guidelines ${ }^{14,15}$.

\section{Prognostic parameters}

The prognosis of ACS was estimated using the major adverse cardiovascular events (MACE) parameters (reinfarction, coronary restenosis and new stenosis, cardiac and non-cardiac rehospitalization, stroke, urgent $\mathrm{CABG}$, mortality) during six-year follow-up. Data were collected by medical examination, checking medical documentation, or telephone contact with patients, family members or home physicians.

\section{Data analysis}

Qualitative data were analyzed by $\chi^{2}$-test. Differences in anthropometric and PA level indices among the groups, as well as PA level indices between the groups and general population were tested by Student's t-test, Mann-Whitney U-test and KruskalWallis ANOVA test. Correlations of anthropometric parameters, activity level and severity, and prognostic parameters were analyzed by using the Spearman rank order correlation analysis. The value of $\mathrm{p}<0.05$ was considered significant. Statistical analysis was carried out in STATISTICA 6.0 for Windows program.

\section{Results}

Out of 116 patients, there were 38 (32.8\%), 30 (25.9\%) and 48 (41.4\%) patients with UAP, NSTEMI and STEMI, respectively. There were significant differences among them in hypertension, diabetes and smoking, as well as in WHR values, but without significant differences in PA (Table 1).

Hypertensive patients were found to have higher values of BMI $\left(\mathrm{kg} / \mathrm{m}^{2}\right)(28.8 \pm 3.8$ vs. $26.9 \pm 3.3, \mathrm{p}=$ 0.039), WC (cm) $(102.3 \pm 10.2$ vs. $97.1 \pm 9.0, \mathrm{p}=0.014)$ and WHR $(0.98 \pm 0.1$ vs. $0.95 \pm 0.1, \mathrm{p}=0.020)$. There were no such differences in BMI, WC and WHR related to the most severity parameters (see the Severity parameters section) and types of treatment (conserva- 
Table 1. Baseline demographic, anthropometric and physical activity values in patients with acute coronary syndrome

\begin{tabular}{|c|c|c|c|c|}
\hline Parameter & $\begin{array}{l}\text { UAP } \\
(\mathrm{n}=38)\end{array}$ & $\begin{array}{l}\text { NSTEMI } \\
(\mathrm{n}=30)\end{array}$ & $\begin{array}{l}\text { STEMI } \\
(\mathrm{n}=48)\end{array}$ & $\mathrm{p}$ value \\
\hline Age (years) ${ }^{\ddagger}$ & $54.8 \pm 7.9$ & $57.0 \pm 5.5$ & $53.5 \pm 7.1$ & 0.095 \\
\hline Male $(\%)^{\S}$ & $30(79.0)$ & $24(80.0)$ & $38(79.2)$ & 0.994 \\
\hline Hypertension $(\%)^{\S}$ & $27(79.4)$ & $25(92.6)$ & $26(57.8)$ & 0.003 \\
\hline Diabetes $(\%)^{\S}$ & $7(20.6)$ & $10(37.0)$ & $4(8.9)$ & 0.015 \\
\hline Dyslipidemia $(\%)^{\S}$ & $27(79.4)$ & $22(81.5)$ & $33(73.3)$ & 0.684 \\
\hline Smoking $(\%)^{\S}$ & $10(29.4)$ & $9(33.3)$ & $27(60.0)$ & 0.012 \\
\hline Height $(\mathrm{cm})^{\ddagger}$ & $173.0 \pm 7.3$ & $174.0 \pm 8.4$ & $175.4 \pm 8.9$ & 0.297 \\
\hline Weight $(\mathrm{kg})^{\ddagger}$ & $82.4 \pm 10.8$ & $84.9 \pm 14.0$ & $90.1 \pm 16.7$ & 0.070 \\
\hline BMI $\left(\mathrm{kg} / \mathrm{m}^{2}\right)^{\ddagger}$ & $27.5 \pm 3.0$ & $27.7 \pm 3.7$ & $29.1 \pm 4.2$ & 0.118 \\
\hline $\mathrm{WC}(\mathrm{cm})^{\ddagger}$ & $99.5 \pm 8.9$ & $100.3 \pm 9.3$ & $102.6 \pm 11.0$ & 0.416 \\
\hline $\mathrm{HC}(\mathrm{cm})^{\ddagger}$ & $104.2 \pm 7.6$ & $101.3 \pm 6.4$ & $103.9 \pm 8.8$ & 0.389 \\
\hline $\mathrm{WHR}^{\ddagger}$ & $0.95 \pm 0.05$ & $0.98 \pm 0.06$ & $0.99 \pm 0.06$ & 0.016 \\
\hline Work index & $2.8 \pm 0.7$ & $2.6 \pm 0.9$ & $2.9 \pm 0.8$ & 0.331 \\
\hline Sports index ${ }^{\ddagger}$ & $2.2 \pm 0.6$ & $2.2 \pm 0.8$ & $2.5 \pm 0.9$ & 0.528 \\
\hline Leisure time index ${ }^{\ddagger}$ & $2.6 \pm 0.6$ & $2.8 \pm 0.6$ & $2.7 \pm 0.7$ & 0.568 \\
\hline Total index ${ }^{\ddagger}$ & $2.6 \pm 0.4$ & $2.6 \pm 0.5$ & $2.7 \pm 0.5$ & 0.473 \\
\hline Inactive/active $(\%)^{\S}$ & $68.4 / 31.6$ & $66.7 / 33.3$ & $62.5 / 37.5$ & 0.838 \\
\hline $\begin{array}{l}\text { Very low active/low active/ } \\
\text { moderately and highly active }(\%)^{\S}\end{array}$ & $21.0 / 47.4 / 25.5$ & $23.3 / 43.3 / 33.4$ & $22.9 / 39.6 / 37.5$ & 0.966 \\
\hline
\end{tabular}

ACS = acute coronary syndrome; $\mathrm{BMI}=$ body mass index; $\mathrm{HC}=$ hip circumference; NSTEMI = myocardial infarction without ST-elevation; STEMI = ST-elevation myocardial infarction; UAP = unstable angina pectoris; $\mathrm{WC}=$ waist circumference; $\mathrm{WHR}=$ waist-to-hip ratio

${ }^{\dagger}$ statistical significance defined as $\mathrm{p}<0.05$; ${ }^{\ddagger}$ data expressed as mean and standard deviation, compared with Kruskal-Wallis ANOVA test; ${ }^{\S}$ data expressed as absolute number and percentage (\%), compared with $\chi^{2}$-test.

tive, PCI, CABG), except for subjects with severe $\mathrm{CAD}$ (i.e. higher number of narrowed coronary arteries) who had higher values of BMI $\left(\mathrm{kg} / \mathrm{m}^{2}\right)(30.2 \pm 3.6$ vs. 27.1 $\pm 3.7, \mathrm{p}=0.023)$ and $\mathrm{WC}(\mathrm{cm})(105.5 \pm 9.8$ vs. $97.5 \pm 10.6, \mathrm{p}=0.024)$. Also, patients with stenosed left anterior descending artery (LAD) and anterior wall MI had higher values of BMI $\left(\mathrm{kg} / \mathrm{m}^{2}\right)(29.6 \pm 3.9$ vs. $27.8 \pm 3.5, \mathrm{p}=0.016$ and $29.7 \pm 3.9$ vs. $27.7 \pm 3.5, \mathrm{p}=0.023$, respectively). There was positive correlation between WHR and maximal CK ( $\mathrm{r}=0.26, \mathrm{p}=0.008)$, and negative correlation between WHR and LVEF values ( $\mathrm{r}=-$ $0.25, \mathrm{p}=0.017$ ).

According to the two-point LRC questionnaire, inactive patients more often had multi-vessel CAD (46\% vs. 20\%) and anterior wall MI (42\% vs. $40 \%)$ as compared with physically active subjects ( $\mathrm{p}<0.05$ all) (Fig. 1). However, when evaluating PA level using four-point LRC PA questionnaire, there was no difference between the groups regarding the parameters of ACS severity and long-term prognosis, or CVD risk factors.

Considering PA level (Baecke questionnaire), patients with higher LI had a lower number of affected coronary arteries, lower rate of stent implantations and lower length of implanted stents, while those with higher WI had a lower rate of anterior wall MI $(\mathrm{p}<0.05$ all) (Fig. 2).

During 6-year follow-up, patients with higher LI (3.1 vs. 2.6) were treated more with CABG, subjects with lower SI had a higher incidence of stroke (1.8 vs. 2.4), while patients with lower values of LI (2.3 vs. 2.8) and TI (2.5 vs. 2.7) had a higher incidence of all-cause mortality ( $\mathrm{p}<0.05$ all) (Fig. 3).

Furthermore, the values of anthropometric parameters and PA level (estimated by Baecke questionnaire) were compared with a representative sample of the Croatian general population ${ }^{16}$. Upon stratification for 


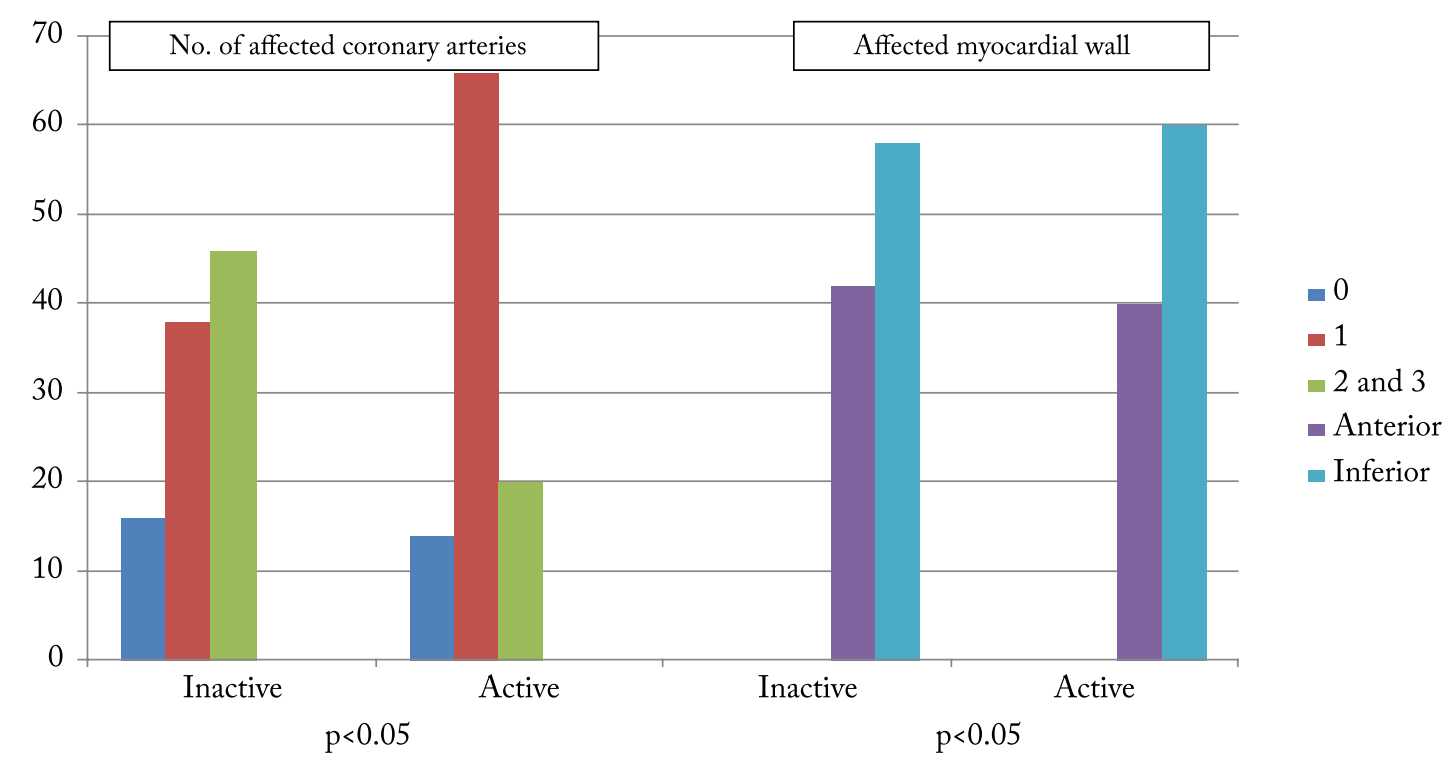

Fig. 1. Effect of physical activity level on coronary artery disease severity estimated by the LRC PA questionnaire.

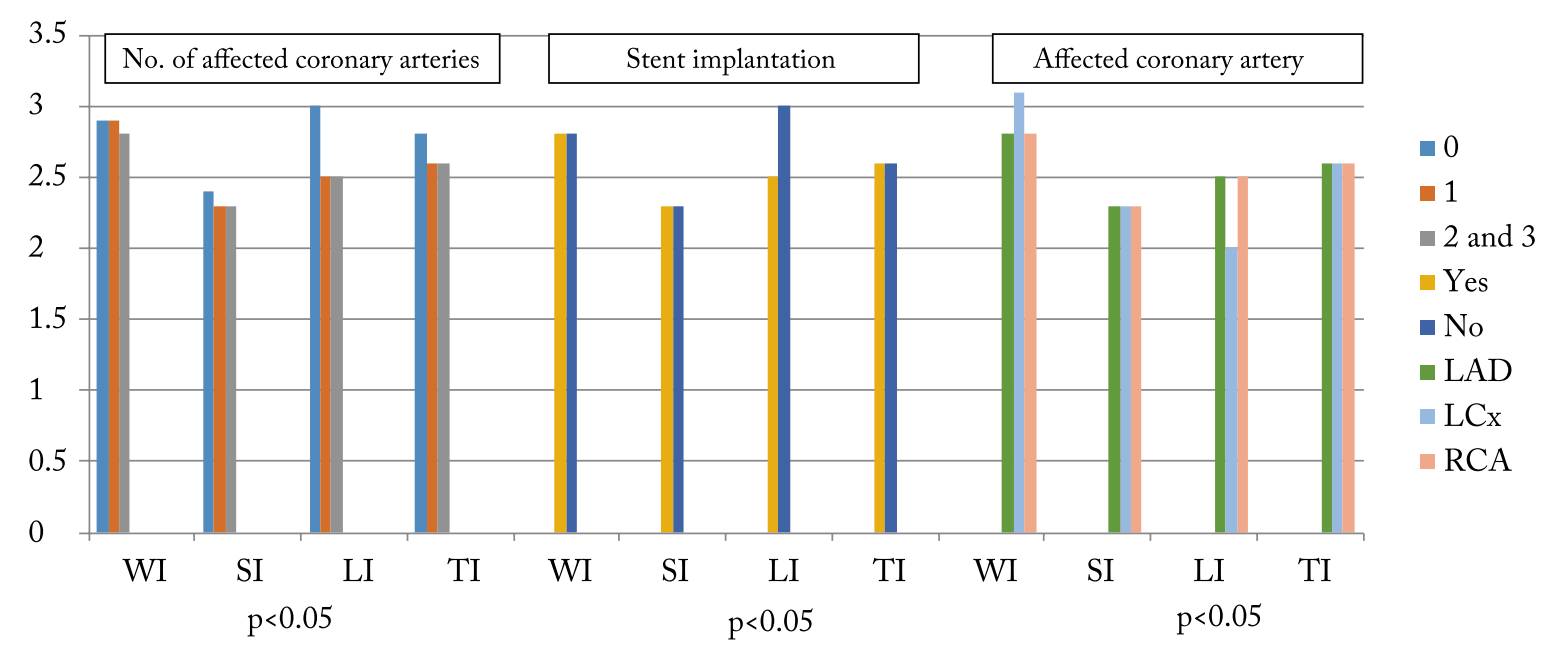

Fig. 2. Effect of physical activity level on coronary artery disease severity estimated by Baecke questionnaire.

$\mathrm{LAD}=$ left anterior descending artery; $\mathrm{LI}=$ leisure time index; $\mathrm{RCA}=$ right coronary artery; $\mathrm{SI}=$ sports index; $\mathrm{TI}=\mathrm{total}$ index; $\mathrm{WI}=$ working index

age and gender, our patients with ACS had higher values of body weight (80 vs. $87 \mathrm{~kg}$ ), WC (94 vs. $101 \mathrm{~cm}$ ) and WHR (93 vs. 98), as well as lower values of LI (3.0 vs. 2.8) and TI (2.8 vs. 2.6) ( $\mathrm{p}<0.05$ all).

\section{Discussion}

Obesity increases the risk of CAD development considerably and independently by up to $50 \% \%^{6,8}$. In our study, patients with UAP had lower WHR in comparison to STEMI and NSTEMI patients, and more obese patients had more severe CAD and ACS. Tehard et al. emphasized strong correlation between PA level estimated by Baecke questionnaire and abdominal type of obesity, especially among men ${ }^{17}$. The Women's Health Study concluded that the risk of CAD associated with elevated BMI was considerably reduced 


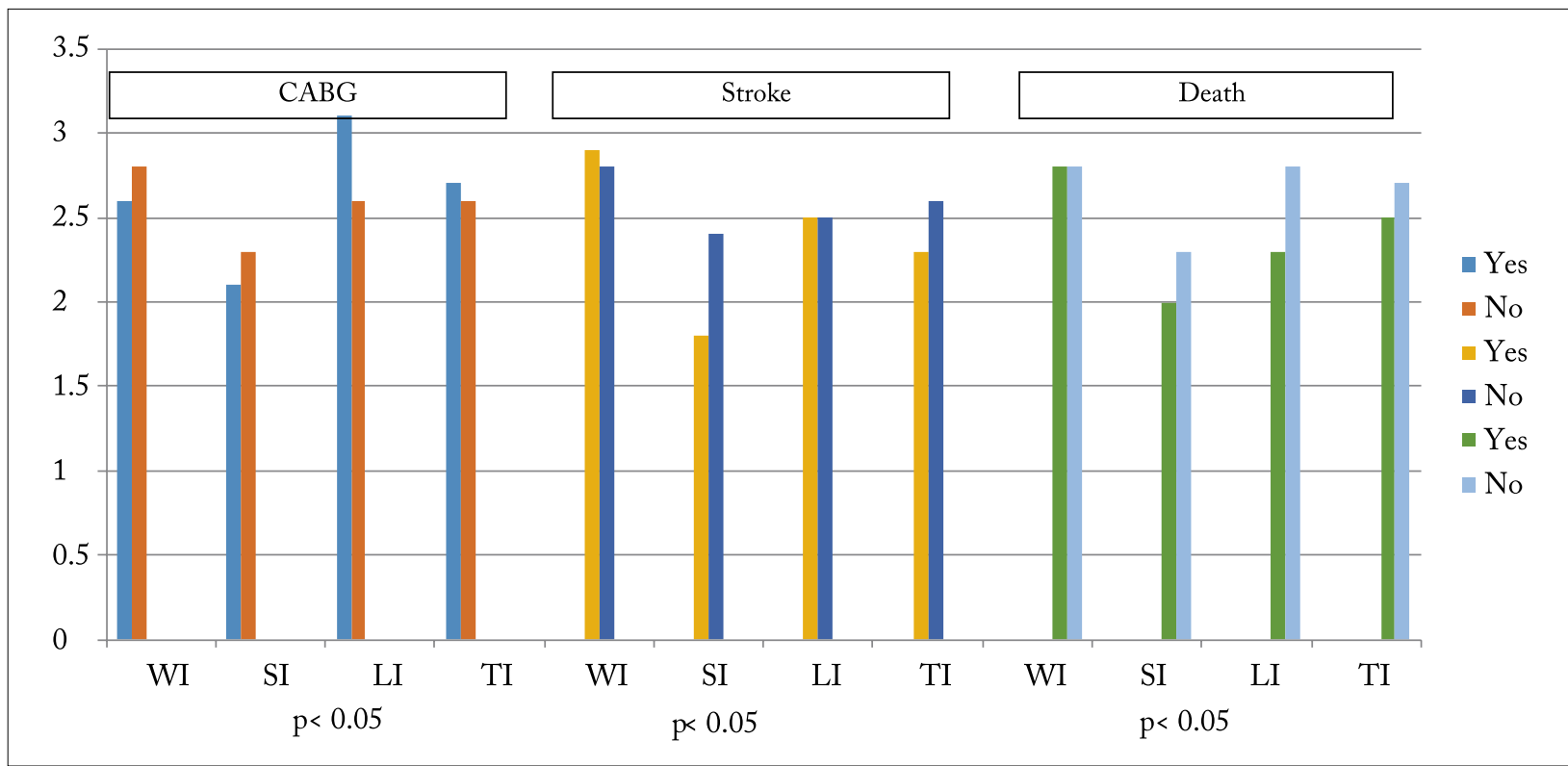

Fig. 3. Effect of physical activity level on long-term prognosis of coronary artery disease estimated by Baecke questionnaire.

$\mathrm{CABG}=$ coronary artery bypass graft; $\mathrm{LI}=$ leisure time index; $\mathrm{SI}=$ sports index; $\mathrm{TI}=$ total index; $\mathrm{WI}=$ working index

but not completely eliminated by increased PA levels ${ }^{18}$. Consequently, anthropometric parameters of obesity (body mass, BMI, WC, WHR) should also be considered as indirect indicators of PA level.

The LRC questionnaire, and especially the twopoint system, is a very simple method to estimate the benefits of PA. According to the literature ${ }^{12,13}$, the four-point method of LRC questionnaire increases the ability to indicate better relation grading between the measures of cardio-respiratory fitness and body fatness, as well as other benefits of PA, which has not been shown in our study where only the two-point method showed statistically significant benefits.

A number of studies have shown that patients with diabetes have a lower level of PA, especially sports activity ${ }^{12,19,20}$, which is in line with the results of our study. According to the literature, there is a positive chronic effect of physical exercise on blood pressure, but certain subgroups of hypertensive patients are more responsive to the blood pressure lowering effect of PA, and it depends on body mass and diastolic blood pressure level ${ }^{12}$. The latter can explain the absence of statistically significant difference in PA level obtained by Baecke questionnaire between hypertensive and non-hypertensive subjects in this study, as well as in other studies ${ }^{21}$.
In this study, concerning all parameters of ACS severity, PA level at work place influenced only the lower incidence of anterior wall MI. Other studies also suggest that PA performed at work place is usually not of adequate intensity, volume and duration to effect positive changes in motor and functional capacities, and to decrease cardiovascular risk factors ${ }^{12,22}$. On the other hand, results of our study confirmed the effect of PA during leisure time, including sports activity, on ACS severity and long-term prognosis. Also, leisure time activity and sports activity are important in decelerating cardiovascular risk factors and arterial stiffness development ${ }^{12,23}$, as well as for cardiac autonomic function and vagal-related heart rate variability indices ${ }^{24}$. These types of activity are associated with better selfestimated overall health status ${ }^{24}$, and interestingly, predisposition to engage in PA is genetically inherited ${ }^{25}$. The above-mentioned is strongly supported by our results according to which the study population had lower leisure time and total PA in comparison with the representative sample of the general population, which is in line with the results of many studies ${ }^{1-6,26}$.

A limitation of our study was its single-center design assessing experience in a small sample of patients. Therefore, our findings should be validated in larger clinical randomized trials. 


\section{Conclusion}

In conclusion, unfavorable effects of obesity and beneficial effects of PA level, especially at leisure time and during sports activity, proven by this study, impose an obligation on health professionals to encourage weight loss and PA as a healthy lifestyle in their patients and general population, which is as important as drug compliance and reduction of other risk factors.

\section{References}

1. Thompson PD, Buchner D, Pina IL, et al.; American Heart Association Council on Clinical Cardiology Subcommittee on Exercise, Rehabilitation, and Prevention; American Heart Association Council on Nutrition, Physical Activity, and Metabolism Subcommittee on Physical Activity. Exercise and physical activity in the prevention and treatment of atherosclerotic cardiovascular disease: a statement from the Council on Clinical Cardiology (Subcommittee on Exercise, Rehabilitation, and Prevention) and the Council on Nutrition, Physical Activity, and Metabolism (Subcommittee on Physical Activity). Circulation. 2003;107:3109-16. doi: 10.1161/01.CIR.0000075572. 40158.77 .

2. Vatten LJ, Nilsen TI, Romundstad PR, Drøyvold WB, Holmen J. Adiposity and physical activity as predictors of cardiovascular mortality. Eur J Cardiovasc Prev Rehabil. 2006;13:909-15. doi: 10.1097/01.hjr.0000239463.80390.52.

3. Arsenault BJ, Rana JS, Lemieux I, et al. Physical inactivity, abdominal obesity and risk of coronary heart disease in apparently healthy men and women. Int J Obes (Lond). 2010;34: 340-7. doi: 10.1038/ijo.2009.229. Epub 2009 Nov 17.

4. Li TY, Rana JS, Manson JE, et al. Obesity as compared with physical activity in predicting risk of coronary heart disease in women. Circulation. 2006;113:499-506. doi: 10.1161/CIRCULATIONAHA.105.574087.

5. König D, Bönner G, Berg A. [The role of adiposity and inactivity in primary prevention of cardiovascular disease]. Herz. 2007;32:553-9. doi: 10.1007/s00059-007-3019-7 (in German)

6. Buttar HS, Li T, Ravi N. Prevention of cardiovascular diseases: role of exercise, dietary interventions, obesity and smoking cessation. Exp Clin Cardiol. 2005;10:229-49. PMCID: PMC 2716237

7. Pollock ML, Franklin BA, Balady GJ, et al. AHA Science Advisory. Resistance exercise in individuals with and without cardiovascular disease: benefits, rationale, safety, and prescription: an advisory from the Committee on Exercise, Rehabilitation, and Prevention, Council on Clinical Cardiology, American Heart Association; Position paper endorsed by the American College of Sports Medicine. Circulation. 2000;101:828-33. doi: 10.1161/01.cir.101.7.828.
8. Ståhle A. [Life-long regular physical exercise is crucial in coronary disease]. Lakartidningen. 2004;101:2988-90. (in Swedish) PMID: 15493636

9. Baecke JA, Burema J, Frijters JE. A short questionnaire for the measurement of habitual physical activity in epidemiological studies. Am J Clin Nutr. 1982;36:936-42. doi: 10.1093/ajen/ 36.5.936.

10. Pols MA, Peeters PH, Bueno-De-Mesquita HB, et al. Validity and repeatability of a modified Baecke questionnaire on physical activity. Int J Epidemiol. 1995;24:381-8. doi: 10.1093/ ije/24.2.381.

11. Misigoj-Duraković M, Heimer S, Matković BR, Ruzić L, Prskalo I. Physical activity of urban adult population: questionnaire study. Croat Med J. 2000;41:428-32. PMID: 11063768

12. Babić Z, Deskin M, Muacevic-Katanec D, Erdeljic V, MisigojDurakovic M, Metelko Z. Estimation of physical activity by different questionnaires in overweight subjects and patients with type 2 diabetes mellitus: relationship with anthropometric and metabolic variables. Diabetes Nutr Metab. 2004;17:280-9. PMID: 16295050

13. Ainsworth BE, Jacobs DR Jr, Leon AS. Validity and reliability of self-reported physical activity status: the Lipid Research Clinics questionnaire. Med Sci Sports Exerc. 1993;25:92-8. doi: 10.1249/00005768-199301000-00013.

14. Van de Werf F, Ardissino D, Betriu A, et al.; Task Force on the Management of Acute Myocardial Infarction of the European Society of Cardiology. Management of acute myocardial infarction in patients presenting with ST-segment elevation. Eur Heart J. 2003;24:28-66. doi: 10.1016/s0195-668x(02)00618-8.

15. Bertrand ME, Simoons ML, Fox KA, et al.; Task Force on the Management of Acute Coronary Syndromes of the European Society of Cardiology. Management of acute coronary syndromes in patients presenting without persistent ST-segment elevation. Eur Heart J. 2002;23:1809-40. doi: 10.1053/euhj. 2000.2301.

16. Heimer S, Misigoj-Duraković M, Ruzić L, et al. Fitness level of adult economically active population in the Republic of Croatia estimated by EUROFIT system. Coll Antropol. 2004;28: 223-33. PMID: 15636079

17. Tehard B, Saris WH, Astrup A, et al. Comparison of two physical activity questionnaires in obese subjects: the NUGENOB study. Med Sci Sports Exerc. 2005;37:1535-41. doi:10.1249/01. mss.0000177464.68521.3b.

18. Weinstein AR, Sesso HD, Lee IM, et al. The joint effects of physical activity and body mass index on coronary heart disease risk in women. Arch Intern Med. 2008;168:884-90. doi: 10.1001/archinte.168.8.884.

19. Stefanov TS, Vekova AM, Kurktschiev DP, TemelkovaKurktschiev TS. Relationship of physical activity and eating behaviour with obesity and type 2 diabetes mellitus: Sofia Lifestyle (SLS) study. Folia Med (Plovdiv). 2011;53:11-8. doi: 10.2478/v10153-010-0022-1.

20. Chien KL, Chen MF, Hsu HC, Su TC, Lee YT. Sports activity and risk of type 2 diabetes in Chinese. Diabetes Res Clin 
Pract. 2009;84:311-8. doi: 10.1016/j.diabres.2009.03.006. Epub 2009 Apr 9.

21. Felmeden DC, Spencer CG, Blann AD, Beevers DG, Lip GY. Physical activity in relation to indices of endothelial function and angiogenesis factors in hypertension: a substudy of the AngloScandinavian Cardiac Outcomes Trial (ASCOT). J Intern Med. 2003;253:81-91. doi: 10.1046/j.1365-2796.2003.01087.x.

22. Ruzic L, Heimer S, Misigoj-Durakovic M, Matkovic BR. Increased occupational physical activity does not improve physical fitness. Occup Environ Med. 2003;60:983-5. doi: 10.1136/ oem.60.12.983.

23. Boreham CA, Ferreira I, Twisk JW, Gallagher AM, Savage MJ, Murray LJ. Cardiorespiratory fitness, physical activity, and arterial stiffness: the Northern Ireland Young Hearts Project. Hypertension. 2004;44:721-6. doi: 10.1161/01.HYP.0000144 293.40699.9a. Epub 2004 Sep 27.
24. Buchheit M, Simon C, Charloux A, Doutreleau S, Piquard F, Brandenberger $G$. Heart rate variability and intensity of habitual physical activity in middle-aged persons. Med Sci Sports Exerc. 2005;37:1530-4. doi: 10.1249/01.mss.0000177556.05 081.77.

25. Choh AC, Demerath EW, Lee M, Williams KD, Towne B, Siervogel RM, et al. Genetic analysis of self-reported physical activity and adiposity: the Southwest Ohio Family Study. Public Health Nutr. 2009;12:1052-60. doi: 10.1017/S13689800 08003583. Epub 2008 Sep 9.

26. Iijima K, Iimuro S, Ohashi Y, et al.; Japanese Elderly Diabetes Intervention Trial Study Group. Lower physical activity, but not excessive calorie intake, is associated with metabolic syndrome in elderly with type 2 diabetes mellitus: the Japanese Elderly Diabetes Intervention Trial. Geriatr Gerontol Int. 2012;12:68-76. doi: 10.1111/j.1447-0594.2011.00814.x.

Sažetak

\section{ULOGA ANTROPOMETRIJSKIH PARAMETARA I STUPNJA TJELESNE AKTIVNOSTI U BOLESNIKA S AKUTNIM KORONARNIM SINDROMOM HOSPITALIZIRANIH U JEDINICI INTENZIVNE KARDIOLOŠKE SKRBI}

\section{Z. Babić, I. Zeljković, H. Pintarić, M. Vrsalović, M. Mornar Jelavić i M. Mišigoj-Duraković}

Antropometrijski parametri imaju ulogu u dijagnostici pretilosti, rizičnog čimbenika akutnog koronarnog sindroma (AKS). Cilj je bio istražiti važnost razine pretilosti i tjelesne aktivnosti na težinu i dugoročnu prognozu AKS-a. Ukupno je 116 bolesnika s AKS-om analizirano prema osnovnim (demografija, povijest bolesti, antropometrija) i parametrima težine (klinička prezentacija, bolničke komplikacije, laboratorijski, ehokardiografski, angiografski) i prognoze (veliki neželjeni kardiovaskularni događaji tijekom šest godina). Razine pretilosti i tjelesne aktivnosti (Baeckeov upitnik i upitnik LRC) uspoređivane su s reprezentativnim uzorkom opće populacije u Republici Hrvatskoj. Bolesnici s većim brojem stenoziranih koronarnih arterija imali su veći indeks tjelesne mase (ITM) i opseg struka (waist circumference, WC); oni sa stenoziranom LAD (left anterior descending coronary artery) i infarktom prednje stijenke imali su viši ITM; omjer struka i bokova (waist to hip ratio, WHR) bio je u pozitivnoj korelaciji s kreatin kinazom i u negativnoj korelaciji s ejekcijskom frakcijom $(\mathrm{p}<0,05)$. Neaktivni su bolesnici češće imali višežilnu koronarnu bolest i prednji infarkt; pacijenti s višim indeksom tjelesne aktivnosti u slobodno vrijeme imali su manji broj stenoziranih koronarnih arterija, manju učestalost ugradnje stentova i manju duljinu stentova, dok su oni s višim indeksom radne tjelesne aktivnosti imali manju učestalost prednjeg infarkta $(\mathrm{p}<0,05)$. Tijekom praćenja, inaktivni bolesnici su imali više moždanih udara i smrti $(\mathrm{p}<0,05)$. Naši bolesnici su imali veću tjelesnu težinu, WC i WHR te niži ukupni kao i indeks tjelesne aktivnosti tijekom slobodnog vremena od opće populacije $(p<0,05)$. U zaključku, AKS je lakši i ima bolju dugoročnu prognozu kod manje pretilih bolesnika s višom razinom tjelesne aktivnosti. Bolesnici s AKS-om su pretili i imaju niži ukupni kao i indeks tjelesne aktivnosti tijekom slobodnog vremena od opće populacije.

Ključne riječi: Tjelesna aktivnost; Antropometrija; Akutni koronarni sindrom; Baeckeov upitnik; Upitnik LRC PA; Prognoza 